\title{
Capacitation of bull spermatozoa and fertilization in vitro of cattle follicular oocytes matured in culture
}

\author{
A. Iritani and $\mathrm{K}$. Niwa \\ Department of Animal Science, College of Agriculture, Kyoto University, Kyoto, Japan 606
}

The maturation of ovarian oocytes in vitro and fertilization after transfer to mated animals have been reported for rabbits (Chang, 1955), sheep (Crosby, Ryan \& Gordon, 1971), pigs (Motlik \& Fulka, 1974; Leman \& Dziuk, 1971) and cattle (Sreenan, 1970; Hunter, Lawson \& Rowson, 1972). In-vitro maturation of follicular oocytes followed by successful fertilization in vitro has been reported for the mouse (Cross \& Brinster, 1970; Iwamatsu \& Chang, 1972; Mukherjee, 1972), rat (Niwa \& Chang, 1975), hamster (Barros \& Munoz, 1974), guinea-pig (Yanagimachi, 1974), rabbit (Brackett, Mills \& Jeites, 1972) and man (Edwards, Bavister \& Steptoe, 1969). There does not, however, appear to be any report on the fertilization in vitro of follicular oocytes matured in vitro for large domestic animals such as cattle. The present experiment was therefore performed to examine the possibility of capacitation of bovine spermatozoa in reproductive tracts isolated from oestrous cows or in the uteri in situ of oestrous rabbits.

Ovaries were removed from cows at a local slaughterhouse and returned to the laboratory in saline at $30^{\circ} \mathrm{C}$ within $1 \mathrm{~h}$. Follicular oocytes were collected at $30^{\circ} \mathrm{C}$ by puncturing the follicles $(2-5 \mathrm{~mm}$ diam.) with a needle. The collected oocytes were washed twice with Kreb's-Ringer bicarbonate (KRB) solution to which was added $1 \mathrm{mg}$ glucose $/ \mathrm{ml}, 5.5 \mathrm{mg}$ sodium pyruvate $/ 100 \mathrm{ml}, 241.9 \mathrm{mg}$ sodium lactate $/ 100 \mathrm{ml}, 4 \mathrm{mg}$ crystalline bovine serum albumin (Armour) $/ \mathrm{ml}, 50 \mu \mathrm{g}$ streptomycin/ $\mathrm{ml}$ and 100 i.u. penicillin/ml (Toyoda \& Chang, 1974). The pH of the medium was adjusted to $7 \cdot 4$. Oocytes at the germinal vesicle stage and with cumulus cells were carefully transferred into a Petri dish containing $0.5 \mathrm{ml}$ modified KRB covered with paraffin oil and cultured for $20-24 \mathrm{~h}$ at $37^{\circ} \mathrm{C}$ in an atmosphere of $5 \% \mathrm{CO}_{2}$ in air until the second metaphase was reached (Satoh, Iritani \& Nishikawa, 1977).

Semen was collected from a Japanese Black Breed bull and about $3 \mathrm{ml}$ semen were washed once with modified KRB. The washed spermatozoa were resuspended in $6 \mathrm{ml}$ modified KRB. One of four portions of the washed spermatozoa was incubated for $12-14 \mathrm{~h}$ at $37^{\circ} \mathrm{C}$ in modified $\mathrm{KRB}$ in an atmosphere of $5 \% \mathrm{CO}_{2}$ in air. Two portions were incubated for $3-4 \mathrm{~h}$ in the isolated genital tract from an oestrous cow obtained from the slaughterhouse based on the time required for capacitation of bull spermatozoa (Iritani, Tsunoda, Miyake \& Nishikawa, 1975). The integrity of the follicles and the oestrous condition of the cows were carefully checked. The volume of sperm suspension and the number of spermatozoa incubated were $0.3 \mathrm{ml}$ and $1.5 \times 10^{8}$ respectively in a uterine horn and $0 \cdot 1 \mathrm{ml}$ and $5 \times 10^{7}$ in an oviduct. After the introduction of spermatozoa, the ovarian end of the oviduct, the uterotubal junction and the cervical end of the uterus were ligated, and the tract was kept in saline for $3-4 \mathrm{~h}$ at $37^{\circ} \mathrm{C}$. The fourth portion of the washed sperm suspension $(0 \cdot 1 \mathrm{ml})$ was introduced into the uterus in situ of a doe pretreated with 6 s.c. injections, each of $0.5 \mathrm{mg}$, of FSH(Armour) followed $12 \mathrm{~h}$ later by an i.v. injection of $75 \mathrm{i} . \mathrm{u}$. HCG immediately after the introduction of the sperm suspension. The does were kept for 12-14 h before being killed for recovery of the spermatozoa on the basis of reports on the capacitation time required for rabbit spermatozoa (Bedford, 1969). After incubation the spermatozoa were recovered by flushing the cow oviducts and uteri and rabbit uteri. Contaminating blood cells were removed by centrifugation at $150 \mathrm{~g}$ for $5 \mathrm{~min}$. All sperm samples were then washed by centrifugation at $500 \mathrm{~g}$ for $10 \mathrm{~min}$. Eggs, fixed overnight in $25 \%$ acetic alcohol 18-21 $\mathrm{h}$ after the introduction of spermatozoa and stained with $1 \%$ aceto-orcein, were examined by phase-contrast microscopy and those undergoing fertilization according to the criteria shown in Plate 1 were identified.

As shown in Table 1 , about $60 \%$ of the follicular oocytes normally matured to the second metaphase. These figures were slightly lower than those obtained in our previous experiments in which 
Table 1. The fertilization in vitro of cattle follicular oocytes matured in culture

\begin{tabular}{|c|c|c|c|c|c|c|c|}
\hline \multirow{2}{*}{$\begin{array}{l}\text { Preincubation (a } \\
\text { of } \\
\text { spermatozoa }\end{array}$} & \multirow{2}{*}{$\begin{array}{l}\text { No. of trials } \\
\text { and reproductive } \\
\text { tracts) used for } \\
\text { incubation }\end{array}$} & \multirow{2}{*}{$\begin{array}{l}\text { Total no. } \\
\text { of oocytes } \\
\text { cultured }\end{array}$} & \multirow{2}{*}{$\begin{array}{l}\text { No. of } \\
\text { oocytes } \\
\text { maturing to } \\
\text { metaphase-II } \\
(\%)\end{array}$} & \multicolumn{4}{|c|}{ No. of oocytes fertilized } \\
\hline & & & & Total (\%) & Telophase-II & $\begin{array}{c}\text { Female } \\
\text { pronucleus* }\end{array}$ & $\begin{array}{c}\text { Both } \\
\text { pronucleit }\end{array}$ \\
\hline $\begin{array}{l}12-14 \mathrm{~h} \text { in } \\
\text { modified KRB }\end{array}$ & $4(-)$ & 62 & $38(61 \cdot 3)$ & $0(0.0)$ & 0 & 0 & $\mathbf{0}$ \\
\hline $\begin{array}{l}3-4 \mathrm{~h} \text { in } \\
\text { oviduct of } \\
\text { oestrous cow }\end{array}$ & $3(6)$ & 48 & $29(60 \cdot 4)$ & $6(20 \cdot 7)$ & 1 & 2 & 3 \\
\hline $\begin{array}{l}3-4 \mathrm{~h} \text { in } \\
\text { uterus of } \\
\text { oestrous cow }\end{array}$ & $3(6)$ & 44 & $27(61 \cdot 4)$ & $5(18 \cdot 5)$ & 1 & 1 & 3 \\
\hline $\begin{array}{l}\text { 12-14 h in } \\
\text { uterus of } \\
\text { oestrous doe }\end{array}$ & $4(8)$ & 78 & $47(60 \cdot 3)$ & $10(21 \cdot 3)$ & 3 & 1 & 6 \\
\hline
\end{tabular}

* Enlarged sperm head, split sperm tail and second polar body also present.

$\dagger$ Split sperm tail and second polar body also present.

$66.7 \%$ of oocytes matured normally under almost similar conditions (Satoh et al., 1977). None of the 38 oocytes inseminated with spermatozoa preincubated in modified KRB appeared to be fertilized or activated parthenogenetically but about $20 \%$ showed clear signs of sperm penetration followed by activation in the other three groups (Table 1 and Plate 1). Only one of the 21 oocytes penetrated was abnormal: as shown in Pl. 1, Fig. 6 the second polar body was not extruded. There was no evidence of polyspermic fertilization in any of the penetrated oocytes. Hunter et al. (1972) reported that the pronuclear eggs were found 21-22 h after transplantation of cattle follicular oocytes matured in vitro into mated animals, and a similar interval from the introduction of spermatozoa to the pronuclear stage was also required in the present experiment.

The present results, especially those indicating the capacitation of bull spermatozoa in the uterus of an oestrous rabbit, suggest that the rabbit uterus could be used for study of the capacitation requirements of spermatozoa from different species, including domestic animals and primates.

This work was supported by a grant from the Ford Foundation (No. 740-0404). One of us (A.I.) is a recipient of a grant from the Ministry of Education (No. 056120). We are grateful to $\mathrm{Mr} \mathrm{E}$. Satoh and Mr M. Miyake for their assistance.

\section{PLATE 1}

Fig. 1. The fertilizing spermatozoon in an oocyte fixed $18 \mathrm{~h}$ after the introduction of spermatozoa preincubated in a rabbit uterus for $14 \mathrm{~h}$. The beginning of nuclear swelling and the detached mid-piece are seen. $\times 880$.

Fig. 2. The fertilizing spermatozoon in an oocyte fixed $20 \mathrm{~h}$ after the introduction of spermatozoa preincubated for $3.5 \mathrm{~h}$ in the isolated uterus from an oestrous cow. $\times 800$.

Fig. 3. A pronuclear egg showing the sperm mid-piece (arrow) in close association with the male pronucleus (M); the female pronucleus (F) and the second polar body (PB) can also be seen. The egg was fixed $21 \mathrm{~h}$ after the introduction of spermatozoa preincubated for $14 \mathrm{~h}$ in a rabbit uterus. $\times 340$.

Figs 4 and 5. The characteristic divergence at the end of the mid-piece (arrow) in close association with the male pronucleus $(M)$ is seen in an egg fixed $18 \mathrm{~h}$ after the introduction of spermatozoa preincubated for $3.5 \mathrm{~h}$ in the isolated uterus from an oestrous cow (Fig. 4) and in an egg fixed $20 \mathrm{~h}$ after the introduction of spermatozoa preincubated for $3.5 \mathrm{~h}$ in the isolated oviduct from an oestrous cow (Fig. 5) $\times 800$.

Figs 6 and 7. A pronuclear egg fixed $18 \mathrm{~h}$ after the introduction of spermatozoa preincubated for $3.5 \mathrm{~h}$ in the isolated uterus from an oestrous cow. Fig. 6. One of two female pronuclei (F) would have become a second polar body. $\times 520$. The arrow shows the location of the sperm tail (Fig. 7) found in a different focal plane near the male pronucleus $(M)$. Note the characteristic divergence of the mid-piece. $\times 800$. 

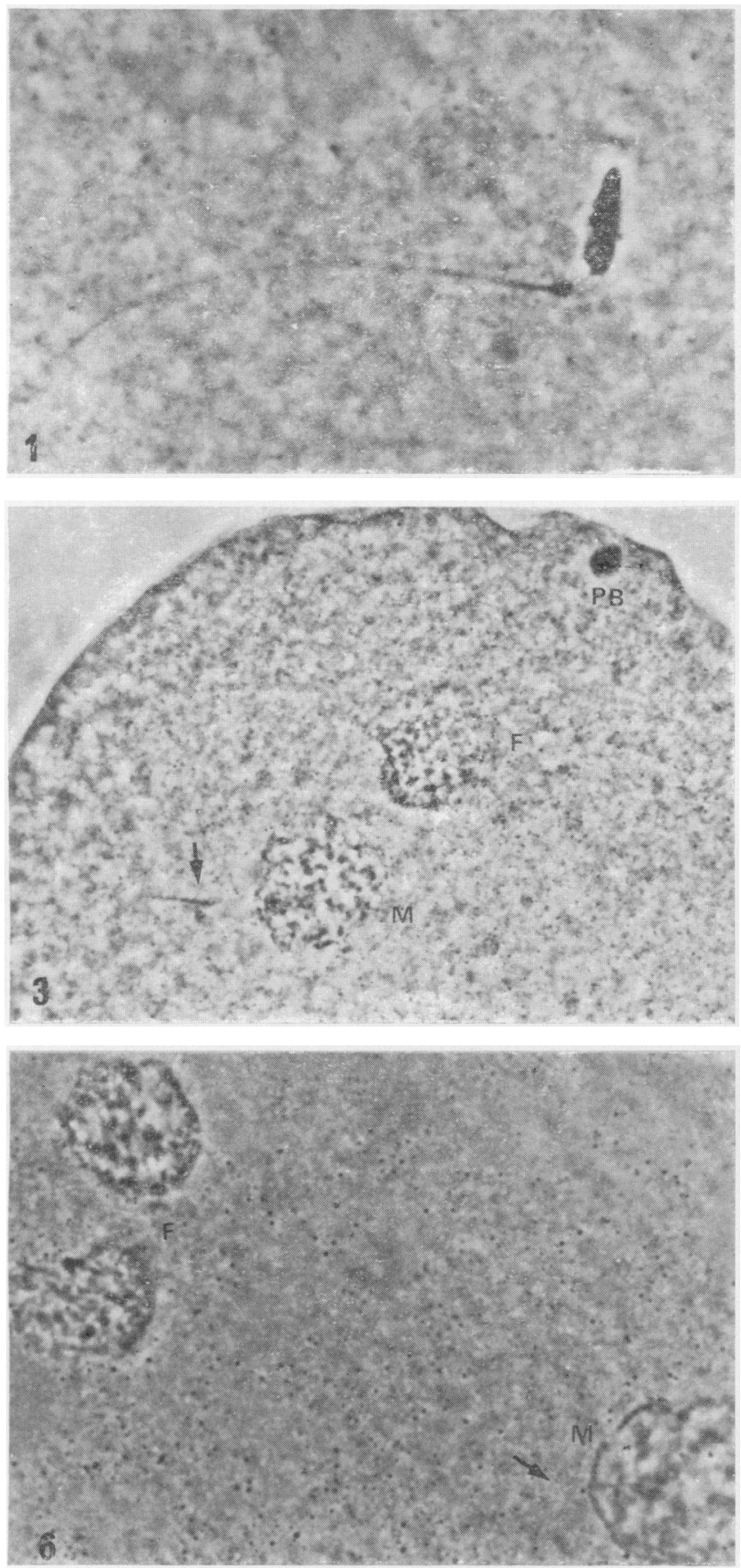
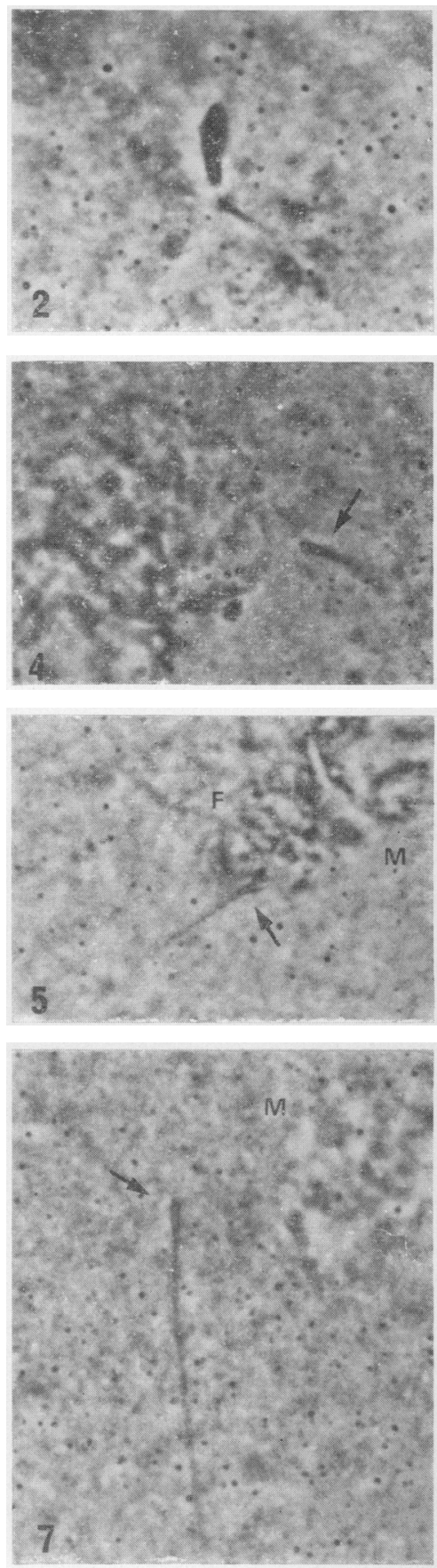


\section{References}

Barros, C. \& Munoz, G. (1974) Sperm penetration through the zona pellucida of immature hamster oocytes. Acta physiol. latinoam. 24, 612-615.

BEDFORD, J.M. (1969) Limitations of the uterus in the development of the fertilizing ability (capacitation) of spermatozoa. J. Reprod. Fert., Suppl. 8, 19-26.

Brackett, B.G., Mills, J.A. \& Jeites, G.G. (1972) In vitro fertilization of rabbit ova recovered from ovarian follicles. Fert. Steril. 23, 898-909.

Chang, M.C. (1955) The maturation of rabbit oocytes in culture and their maturation, activation, fertilization and subsequent development in the Fallopian tubes. J. exp. Zool. 128, 379-406.

Crosby, T.F., Ryan, P.O. \& Gordon, I. (1971) Culture and fertilization of sheep ovarian oocytes. IV. Observations on sperm penetration in oocytes transfered to the sheep oviduct. J. agric. Sci., Camb. 76, 379-382.

Cross, P.C. \& Brinster, R.L. (1970) In vitro development of mouse oocytes. Biol. Reprod. 3, 298-307.

Edwards, R.G., Bavister, B.D. \& Steptoe, P.C. (1969) Early stages of fertilization in vitro of human oocytes matured in vitro. Nature, Lond. 221, 632-635.

HunTER, R.H.F., LAwson, R.A.S. \& Rowson, L.E.A. (1972) Maturation, transplantation and fertilization of ovarian oocytes in cattle. J. Reprod. Fert. 30, 325328.

Iritani, A., Tsunoda, Y., MiYake, M. \& NishikaWA, Y. (1975) Enhanced respiration and reduction of tetracycline binding of boar and bull spermatozoa following incubation in the female genital tract. Jap. J. zootech. Sci. 46, 531-537.
Iwamatsu, T. \& ChaNG, M.C. (1972) Sperm penetration in vitro of mouse oocytes at various times during maturation. J. Reprod. Fert. 31, 237-247.

LemaN, A.D. \& DzIUK, P.J. (1971) Fertilization and development of pig follicular oocytes. J. Reprod. Fert. 26, 387-389.

Motl.1K, J. \& FulKA, J. (1974) Fertilization of pig follicular oocytes cultivated in vitro. J. Reprod. Fert. 36, 235-237.

MukHERJEe, A.B. (1972) Normal progeny from fertilization in vitro of mouse oocytes matured in culture and spermatozoa capacitated in vitro. Nature, Lond. 237, 397-398.

Niwa, K. \& Chang, M.C. (1975) Fertilization of rat eggs in vitro at various times before and after ovulation with special reference to fertilization of ovarian oocytes matured in culture. J. Reprod. Fert. 43, 435451.

Satoh, E., Iritani, A. \& Nishikawa, Y. (1977) Factors involved in maturation of pig and cattle follicular oocytes cultured in vitro. Jap. J. Anim. Reprod. 23 (in press).

SREENAN, J. (1970) In vitro maturation and attempted fertilization of cattle follicular oocytes. J. agric. Sci., Camb. 75, 393-396.

Toyoda, Y. \& Chang, M.C. (1974) Fertilization of rat eggs in vitro by epididymal spermatozoa and the development of such eggs following transfer. $J$. Reprod. Fert. 36, 9-22.

YANAGIMACHI, R. (1974) Maturation and fertilization in vitro of guinea-pig ovarian oocytes. J. Reprod. Fert. $38,485-488$. 